\title{
Assessing a Long-Standing Conservation Program: Mariner's Perspectives on the North Atlantic Right Whale, Eubalaena glacialis, Mandatory Ship Reporting System
}

\author{
GREGORY K. SILBER and KRISTY WALLMO
}

\section{Introduction}

Policies and regulations established to protect the marine environment include measures to reduce perturbations of entire ecosystems (coral reefs: Bellwood et al., 2004), safeguard key habitats on large scales (Marine Protected Areas: Hoyt, 2011, IUCN-WCPA, 2008), and conserve marine species whose population sizes have declined to unsustainable levels (threatened or endangered species: NOAA, 2015). In the United States, the Endangered Species Act (ESA) provides legal protection for threatened and endangered marine (and terrestrial) species, while agencies including the National Ma-

Gregory K. Silber is with the Office of Protected Resources, National Marine Fisheries Service, NOAA, 1315 East West Highway, Silver Spring, MD 20910. Kristy Wallmo is with the Office of Science and Technology, National Marine Fisheries Service, NOAA, 1315 East West Highway, Silver Spring, MD 20910.

doi: dx.doi.org/10.7755/MFR.78.3-4.3 rine Fisheries Service (NMFS), the U.S. Fish and Wildlife Service (FWS), and, less frequently, the U.S. Coast Guard (USCG), are charged with developing and implementing strategies and actions aimed at recovering these species, most often through reduction of ongoing anthropogenic threats.

Establishing conservation actions may result in unintended economic or operational impacts, but subsequent assessments to determine whether they are meeting expected conservation objectives are few (Halpern, 2003; Selig and Bruno, 2010). Refining these actions through assessment and monitoring has the potential to improve both their conservation value and their costeffectiveness (Bruner et al., 2004; Miteva et al., 2012).

In this paper we report findings from an online survey of the maritime industry designed to evaluate a Mandatory Ship Reporting (MSR) system-a long-standing program to raise awareness about and to reduce ship collisions with North Atlantic right whales, Eubalaena glacialis. Since 1999, provisions of the MSR have required ships weighing 300 gross tons (gt) or greater to report their location, speed, and destination to a shore-based station when entering key right whale nursery and feeding areas off the U.S. east coast.

In return, reporting ships receive a message, automatically generated, delivered directly to the ship's bridge, providing information about the risk of vessel collisions with right whales and actions mariners can take to avoid collisions (Silber et al., 2015). The MSR system is distinct from and predates other regulations in place to reduce ship collisions with right whales, such as ship speed reductions.

Our survey examined three aspects of the MSR system: 1) the degree to which mariners comply with the reporting requirements of the system, 2) the operational burden of compliance to captains and crew, and 3) their opin-
ABSTRACT-Measures established to protect living marine resources, including those for endangered marine species, are only infrequently evaluated. In this paper we report findings of an online survey designed to solicit the views of maritime industries about a long-standing endangered large whale conservation program: the Mandatory Ship Reporting (MSR) system. The MSR was established in 1999 to aid in reducing the threat of vessel collisions with the highly depleted North Atlantic right whale, Eubalaena glacialis. Under MSR provisions, vessels $\geq 300$ gross tons are required to report their location, speed, and destination when entering two key right whale aggregation areas. In return, reporting ships are sent an automated message about right whale vulnerability to ship collisions. The survey was intended to obtain views about the extent to which vessel operations were interrupted by the reporting requirement; how mariners utilize, if at all, information provided in the return message; whether vessel operations were modified in response to guidance provided; and the overall importance and effectiveness of the reporting systems in helping ships avoid right whale interactions.

A total of 119 mariners with broad representation of vessel types and decades of experience at sea took part in the survey; 56 of these indicated they had entered one of the MSR areas at least once. Most (ca. 70\%) indicated that they comply with the reporting requirement, distribute information on right whales and ship strikes to crew members, that they were more alert about avoiding/watching for right whales, and that the ships operation may change to avoid an interaction. Of the survey-takers who had entered the system, about half indicated the MSR system is useful for educat- ing captains and crew about right whales and important for right whale conservation, but only about a quarter indicated that it is useful in helping ships avoid right whales. About $40 \%$ said it is an unnecessary requirement for ships. We conclude that as an outreach tool and a means to provide information directly to domestic and international mariners entering right whale habitat for over 15 years (thus, tens of thousands of ships entering these waters have received the message), the MSR almost certainly has been beneficial in educating mariners about the issue of ship strike and in providing guidance on avoiding ship strikes. Views reflected in the survey suggest that, at least from the mariners' perspective, the MSR program has provided positive conservation value; however, not all mariners took specific strike avoidance action after having received the message. 
ions about the utility of the system for reducing collisions and raising awareness about right whale conservation. Though several studies have focused on maritime industry compliance with large whale conservation regulations such as ship speed reduction in seasonally and dynamically managed areas (Lagueux et al., 2011; Asaro, 2012; Silber et al., 2014), few have examined the effectiveness of these regulations in reducing ship-whale collisions (Silber and Betteridge, 2012; Laist et al., 2014; van der Hoop et al., 2014). Further, none of these studies utilized data or observations from mariners themselves.

To date, only Reimer et al. (2016) have collected data directly from mariners in a survey about receptivity to real-time conservation technology. That study found that most mariners surveyed would be interested in receiving information on endangered whales and whale alerts via ships Navigational Telex (NAVTEX) and Automatic Identification Systems (AIS), and that most believed that receiving this information would not be disruptive to their operations (Reimer et al., 2016).

To our knowledge no study has examined mariners' perceptions of existing whale conservation measures and their utility in reducing the likelihood of ship-whale collisions. Our study directly addresses this gap regarding one such conservation measure by directly canvassing mariner viewpoints on use and compliance with reporting into the MSR, its overall conservation value, and impact on ship operations. Our findings add to the limited literature on the burden and overall utility of actions aimed at conserving large whales.

Survey results suggest the conservation value of the MSR program is likely positive because mariners indicated it raised awareness about the whale-strike issue. However, because the intent of the program is to provide information only, and not all mariners altered operations after receiving guidance in the return message, the overall biological impact of program may be somewhat limited.

\section{Background of Ship-Whale Collisions and the MSR System}

Most large whale species were the focus of intensive commercial hunting and were severely depleted globally. Although a number of these populations began to rebound not long after an international moratorium on commercial whaling in 1985-1986, unintended ship-whale collisions and other threats to population recovery remain. In the case of the North Atlantic right whale, population growth has been slow and deaths caused by violent strikes from large ships and fatal entanglement in commercial fishing gear are among the main impediments to recovery of this species (Clapham et al., 1999; Kraus et al., 2005; NMFS ${ }^{2}$ ).

North Atlantic right whales occur near and migrate along the eastern seaboard of Canada and the United States, where large human population centers and co-occuring water-borne commerce, commercial fishing, and other activities are also concentrated. Right whale feeding/socializing aggregation areas occur in waters off New England and eastern Canada and in nursery areas off the South Carolina to Florida coasts. The right whale is vulnerable to collisions with vessels throughout its range, but the threat may be particularly high in these aggregation areas where substantial vessel traffic also occurs (NMFS ${ }^{2}$ ).

Recognizing the influence of human activities on the recovery of right whales, the international community began taking steps to reduce the impact of these threats in the 1990's. Not all ship operators, and maritime commerce industries as a whole, were familiar with the risk that vessels underway posed to right whales and other large whale species. Thus, the conservation community began addressing this concern by focusing pri-

\footnotetext{
${ }^{1}$ International Whaling Commission. Catch limits and catches taken (https://iwc.int/catches).

${ }^{2}$ NMFS. 2005. Recovery plan for the North Atlantic Right Whale (Eubalaena glacialis). U.S. Dep. Commer., NOAA, Natl. Mar. Fish. Serv., Off. Protect. Resourc., (http://www.nmfs.noaa. gov/pr/pdfs/recovery/whale_right).
}

marily on raising mariner awareness about the issue.

Among these actions was the creation of two Mandatory Ship Reporting systems (MSR) as a means to reduce the occurrence of "ship strikes" with right whales (Silber et al., 2015; $\left.\mathrm{USG}^{3}\right)$. A proposal initiated by the United States, backed by other nations and publicly endorsed by President William J. Clinton in April 1998 (Clinton, 1998), to establish the MSR was submitted to the International Maritime Organization (IMO) in June 1998. It was approved by the IMO in December 1998. This was the first formal IMO action to reduce the threat of ship collisions with whales (Luster, 1999), and its first formal action on behalf of any endangered marine species (Johnson, 2004).

\section{Operation of the MSR}

The goal of the MSR is to provide timely information about ship-whale collisions directly to individual vessels as they enter key right whale feeding and nursery habitats. Under the system, ships are required to report their location and time of entry into the system; in return, each reporting ship receives an automated message providing information on ways to reduce the chances of a striking a whale.

Under the rule, self-propelled commercial ships $\geq 300$ gt are required to report to shore-based stations when they enter either of two regions off the eastern U.S. coast where and when right whales are known to occur: one off the state of Massachusetts operates year-round; the other, off the states of Georgia and Florida, is operational annually from 15 Nov. through 15 Apr. (Silber et al., 2012a) (hereafter, referred to as WHALESNORTH and WHALESSOUTH, respectively) (Fig. 1).

Incoming messages are sent primarily via satellite and include ship

${ }^{3}$ U.S. Government. 1998. Ship reporting systems for the eastern coast of the United States. Proposal submitted to the IMO's Sub-Committee on Safety of Navigation. Online at http://www. nmfs.noaa.gov/pr/pdfs/shipstrike/imo_proposal. pdf. 
name, course, speed, and destination among other things. Only reporting is required; no other changes to vessel operations are required. An automatically-generated message is returned to the reporting vessel that includes information on locations of recentlysighted right whales; procedural guidance to help prevent vessel-whale collisions; and information regarding protecting right whales from vessel strike (Fig. 2). Only vessels entering the prescribed areas are required to send a report, therefore only these vessels receive the automatic return message.

Following IMO endorsement, the USCG issued a Final Rule in the U.S. Federal Register (USCG, 2001) that codified the systems by amending the U.S. Code of Federal Regulations (33 CFR 169). The National Oceanic and Atmospheric Administration (NOAA) then added the MSR areas to relevant nautical charts and incorporated the new requirements into various navigational aids such as the U.S. Coast Pilot and elsewhere. ${ }^{4}$

The two MSR systems became effective on 1 July 1999 and have been in operation continuously since that time. From July 1999 to present, operation and administration of this program have been jointly run by the USCG and NOAA's NMFS. All shipto-shore and shore-to-ship communication costs are borne by these two agencies (including a government contract to the communications provider).

Reporting data from these systems have been useful in characterizing vessel operations within the areas (WardGeiger et al., 2005), particularly as it relates to the recovery of right whales. Among other things, incoming MSR reports provided information on U.S. east coast port arrivals and vessel operations which helped form the basis for subsequent ship strike-reduction measures.

${ }^{4}$ See, for example USCG, Local Notice to Mariners. Coastal Waters from Eastport, Maine to Shrewsbury, New Jersey. Special Notices, No. 27/99. Online at http://www.nmfs.noaa.gov/pr/ pdfs/shipstrike/uscg_lnm0799.pdf.
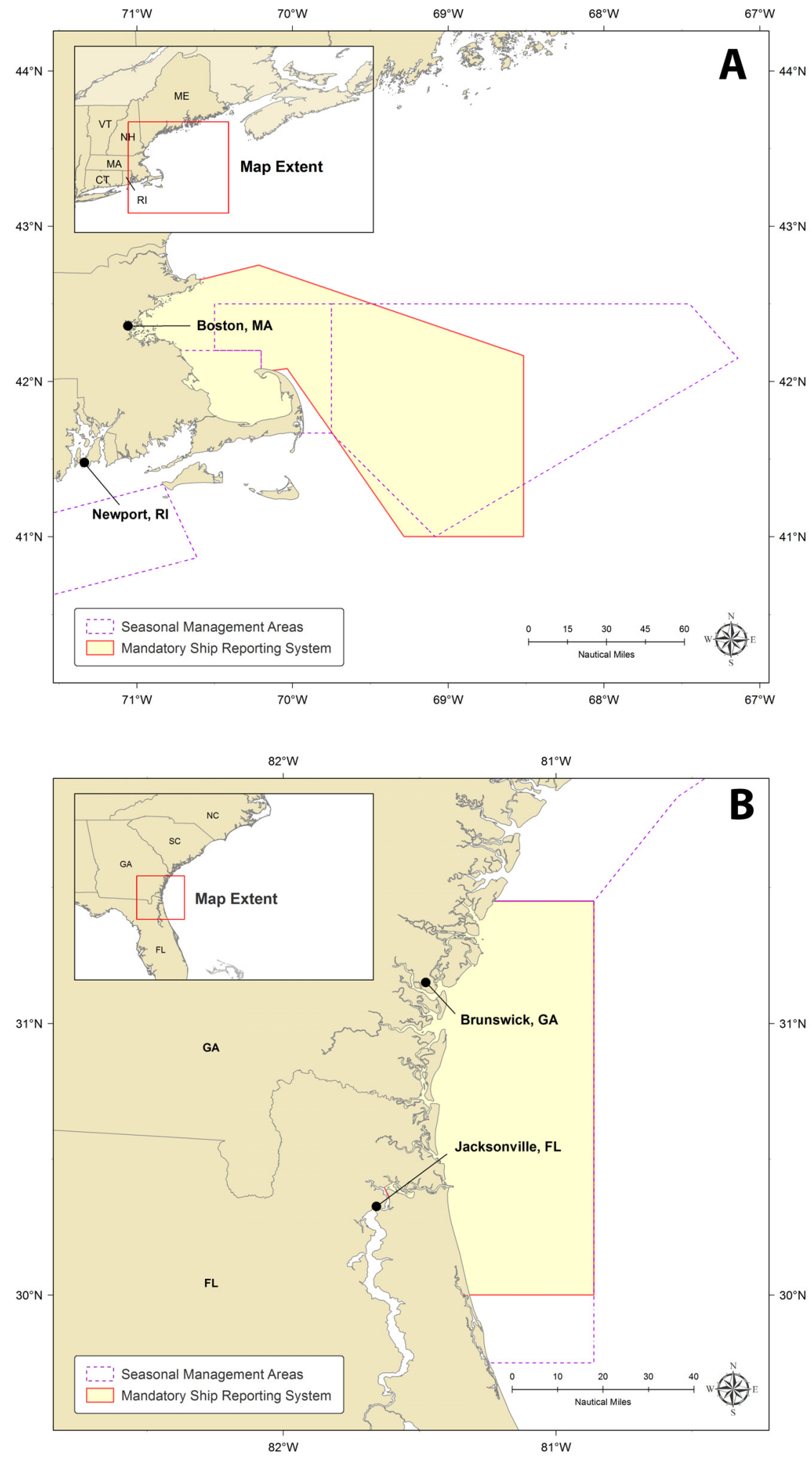

Figure 1.-Mandatory Ship Reporting System Area Boundaries. Also shown are vessel speed restriction seasonal management area boundaries (NOAA, 2008). 
THE CRITICALLY ENDANGERED RIGHT WHALE MAY BE ENCOUNTERED IN OFFSHORE AND COASTAL WATERS. RIGHT WHALES ARE SLOW MOVING AND AT RISK OF SERIOUS INJURY OR DEATH DUE TO COLLISIONS WITH VSLS. VSL OPERATORS ARE REMINDED TO USE CAUTION AND PROCEED AT SAFE SPEEDS IN AREAS USED BY RIGHT WHALES. INTENTIONALLY APPROACHING WITHIN 500 YARDS OF RIGHT WHALES IS PROHIBITED AND IS A VIOLATION OF U.S. LAW. A MINIMUM DISTANCE OF 500 YARDS MUST BE MAINTAINED FROM A SIGHTED WHALE UNLESS HAZARDOUS TO THE VSL OR ITS OCCUPANTS. THE NATIONAL OCEANIC AND ATMOSPHERIC ADMINISTRATION (NOAA) RECOMMENDS THAT OPERATORS ASSUME THAT ANY WHALE SIGHTED IS A RIGHT WHALE.

\section{NOAA REQUIRES MOST VSLS 65 FT OR GREATER TO TRAVEL AT SPEEDS OF 10 KNOTS OR LESS IN SEASONAL MANAGEMENT AREAS USED BY RIGHT WHALES WHEN CONSISTENT WITH SAFETY OF NAVIGATION.}

\section{PLEASE REPORT ALL RIGHT WHALE SIGHTINGS AND COLLISIONS TO 978-585- 8473 OR 978-585-8473 RESPECTIVELY OR TO THE COAST GUARD VIA CHANNEL 16. FOR MORE INFO, CONSULT THE U.S. COAST PILOT.}

Figure 2.- USCG Mandatory Ship Reporting System WHALESNORTH automated return message.

A recent 15-plus-year retrospective analysis of incoming reports (Silber et al., 2015) determined that hundreds of individual ships made over 45,000 reports into the system between July 1999 and December 2013. While generally regarded as a successful and valued outreach tool, the current study is the first attempt to gauge the attitudes and perceptions of mariners regarding conservation benefits as well as the potential impacts to reporting vessels, and to evaluate the ongoing utility and relative value of this longstanding program.

\section{Materials and Methods}

An online survey was developed by NMFS economists and biologists during June-August 2014 to collect data on mariner awareness, attitudes, and use of the MSR system. Because the sampling strategy was opportunistic with an unknown universe, an important consideration in the survey design was to minimize the overall survey length and develop clear and concise questions. To help ensure that these considerations were met and that the overall survey was easy to comprehend, a draft instrument was tested in a focus group on 17 Sept. 2014 in Baltimore, Md., at the Maritime Institute of Technology and Graduate Studies/Pacific Maritime Institute (MITAGS-PMI).

Focus group participants were recruited from a pool of mariners who were attending a course at MITAGSPMI and agreed to participate in a voluntary discussion about the MSR system and the survey. Based on feedback from the focus group, a final survey instrument was developed that contained eight questions and an opportunity to provide open-ended comments at the end of the survey.

The survey (Appendix I), which was implemented online in early June 2015, was programmed by a private consulting firm, ECS Federal ${ }^{5}$, and

${ }^{5}$ Mention of trade names or commercial firms does not imply endorsement by the National Marine Fisheries Service, NOAA. hosted on a domain purchased specifically for the survey implementation. The target survey population was ship owners, operators, or captains who had entered either WHALESNORTH or WHALESSOUTH one or more times.

During an average year, several thousand separate trips are made into both areas (Silber et al., 2015) (some ships and masters may enter multiple times per year). The information needed to directly contact individual ship captains, owners, and/or crews to conduct a survey is not available, making a sampling frame infeasible to develop. For this reason, an opportunistic or convenience sample was necessary.

We acknowledge that this type of sampling has a number of limitations, including the inability to a) examine response bias, b) compute statistical errors, and c) make inferences to a larger population. However in our case, due to the lack of individual contact information, an opportunistic sample involving broad outreach to the generalized community was the only 
viable approach for contacting vessel operators. Ferber (1977) noted that while opportunistic samples are less desirable than samples derived from a systematic approach, they have utility for exploratory purposes or to obtain different views on the dimensions of an issue or problem.

To implement the survey, federal and private entities who engage in activities or communicate regularly with maritime entities were asked to distribute information about the survey (Appendix II). Announcements of the availability of the survey were also sent via association and government email distribution lists shortly after the survey opened.

The announcements of the survey provided potential respondents with a brief description of the survey, why their participation was important, and a link to the online survey. Two additional announcements about the survey were distributed in August and September 2015.

Respondents who chose to participate in the survey were asked eight questions. The first set of questions asked about familiarity with the MSR system and their ship transits through the MSR areas. The second set of questions asked about compliance with, burden of, and conservation potential of the MSR system. The remaining questions asked for the number of years in the industry and type of ship the respondent currently worked on (container ship, passenger vessel, etc.). The survey remained open through 10 Jan. 2016, at which time the URL for the survey was deactivated. The analysis included simple frequency counts of responses to each question.

\section{Results}

\section{Respondent Characteristics}

A total of 119 mariners took part in the survey. Of this number 85 respondents said they were aware of the MSR system (34 people who accessed the survey but entered no response whatsoever or indicated they had no experience or were not familiar with the MSR, were excluded from the analysis) and 56 indicated they had entered one of the MSR areas at least once.

Due to the publicity of the MSR and its support from the IMO, it is possible that mariners who have never entered one of the MSR areas were still familiar with the system and the reporting requirements, and therefore we considered a total of 85 survey-takers eligible to answer a subset of the survey questions. Questions that required direct experience and use of the MSR were only shown to respondents who stated they had entered an MSR area at least once.

Among the 85 respondents who were aware of the MSR, representation of vessel types was broad, and included container ships, tankers, cargo or bulk carriers, RO-RO's (i.e., car and vehicle carriers), cruise ships, passenger vessels (i.e. ferries, whale watching vessels), research ships, and pleasure craft. According to Rodrigue et al. (2017) the global maritime industry has about 100,000 vessels $(>100 \mathrm{t})$ consisting of passenger, bulk carrier, general cargo, and roll-on/rolloff vessels; about $69 \%$ of shipping ton-miles is accounted for by bulk carriers. Our sample consists of captains and crew from all four types of vessels, and about $53 \%$ of respondents cited they worked on bulk carriers.

The years of service in the maritime industry ranged from 2 to 48 years, with $23 \%$ working less than 20 years and $77 \%$ working more than 20 years. The average number of years respondents have worked in the maritime industry was 26, with an average of 11 years as a crew member and 11 years as a captain.

Of the 56 respondents indicating they had entered one of the MSR areas at least once, about $44 \%$ said they entered one of the areas regularly. The number of times respondents said they entered one of the areas during a year ranged from 1 to 100 , with a mean of 27.8 . About $35 \%(n=20)$ indicated they enter WHALESNORTH most frequently, 29\% $(n=16)$ entered the WHALESSOUTH most often, and $35 \%(n=20)$ indicated they enter both areas about the same amount.
As noted, our data is based on an opportunistic sample of ship captains and crew. While the vessel types in our data are representative of the types of vessels in the maritime industry as described by Rodrigue et al. (2017), we cannot determine whether respondent's opinions and attitudes toward the MSR system are representative of those of the larger industry, and specifically those ships that transit the MSR areas.

\section{Compliance with the MSR System}

Most respondents comply with the reporting requirement of the MSR system. About $75 \%$ of respondents $(n=42)$ stated that they send the required report always or most of the time; and slightly less than a fourth of them $(24 \%)$ said they rarely or never send the report. About $82 \%(n=46)$ of respondents stated that they receive a return message about right whales after sending in their ships' report, while the remainder $(n=10)$ indicated they did not receive a return message via the system.

Survey-takers were asked about their level of agreement with four statements related to the transmittal of required ship information when entering an MSR area: 1) it is relatively easy to send in the required report, 2) I generally follow the report format exactly as specified in the instructions, 3) I send in the report as soon as possible, and 4) sending in the required report takes time away from other duties I have on the ship. Of those responding to this portion of the survey, half $(n=20)$ indicated it was easy to send in the report, with over $70 \%$ stating that they followed the required format and they sent in the report as soon as possible after entering the area. About half said that sending in the report takes time away from other duties on the ship (Fig. 3).

\section{Attitudes Toward the MSR System}

Following these statements respondents were asked about their level of agreement with four statements related to the automated right whale conser- 
After entering the MSR area...

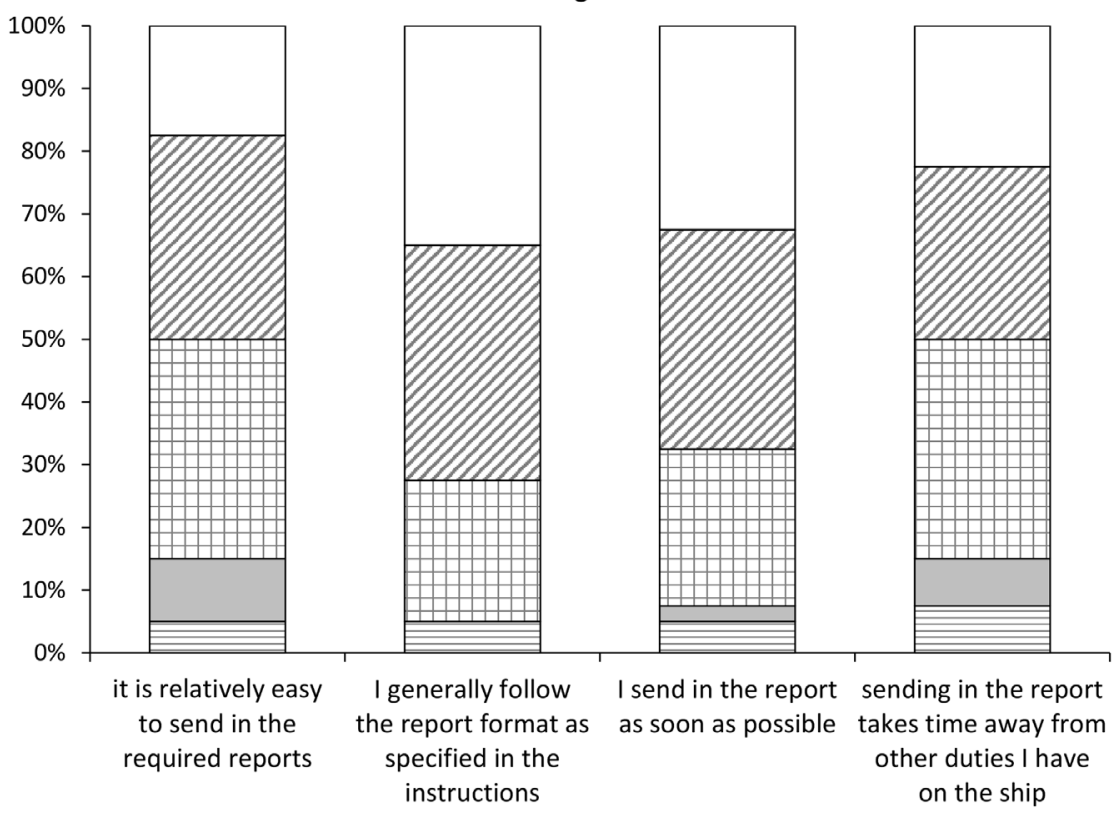

\begin{tabular}{|l|}
\hline$\square$ Strongly Agree \\
$\square$ Somewhat Agree \\
$\square$ Neither Agree nor Disagree \\
$\square$ Somewhat Disagree \\
$\boxminus$ Strongly Disagree \\
\hline
\end{tabular}

Figure 3.-Attitudes toward Mandatory Ship Reporting system ship requirements.

vation information they receive after reporting into the system: 1) I generally don't have time to read the entire message, 2) I am more alert about avoiding or watching for right whales, 3) I find the information to be useful for the captain and crew, and 4) some aspect of the ship's operation may change (e.g., speed, post extra lookouts) to avoid an interaction. Among those responding to all the questions in this section of the survey $(n=25)$, $60 \%$ don't read the entire message, but over half said they are more alert about avoiding/watching for right whales and may change the ships operation to avoid an interaction. Nearly $80 \%$ of respondents stated they distributed the information in the message to captains and/or crew (Fig. 4).

All respondents who stated that they were aware of the system $(n=85)$, even if they had not entered an MSR area, were asked about their level of agree- tion; others said it had little utility in reducing strikes of whales. A few of those providing comments reiterated that reporting into the systems was not a significant or time-consuming task, some suggested using alternative vessel tracking systems in lieu of the MSR. Apparently, a number of respondents believed the survey to include discussion of vessel speed restrictions in addition to the MSR, while others took the opportunity to comment on right whale vulnerability (or their lack of vulnerability) to ship collisions, the utility of right whale protective measures generally, or to offer suggestions on ways to diminish the impact of right whale conservation on maritime industries.

\section{Discussion}

The invitation to participate in the survey was distributed on a broad scale, and we believe that hundreds of mariners were at least aware of the survey. However, the exact number of individuals who received notification of the survey remains unknown; therefore, a response rate is also not known. We expected the number of respondents to be a small fraction of the total number reached for several reasons.

First, previous studies (Ranmuthugala et al., 2008) have shown that opportunistic sampling generates relatively low responses relative to the number of individuals targeted through broadly cast notification efforts, and there was likely considerable overlap in the entities described in Appendix II.

Second, not all mariners are familiar with the MSR program, because a) it applies only to ships sailing in waters along parts of the U.S. eastern seaboard; b) of these, not all ships enter certain U.S. east coast ports (e.g., Boston, Mass., Jacksonville, Fla.) where MSR areas are situated; and c) not all ships meet the 300 gt threshold for reporting. And, finally, there is little reason to expect ship captains sailing under a non-U.S. flag to complete a voluntary survey focused on a U.S. policy implemented by U.S. Federal agencies.

The nature of an opportunistic sam- 


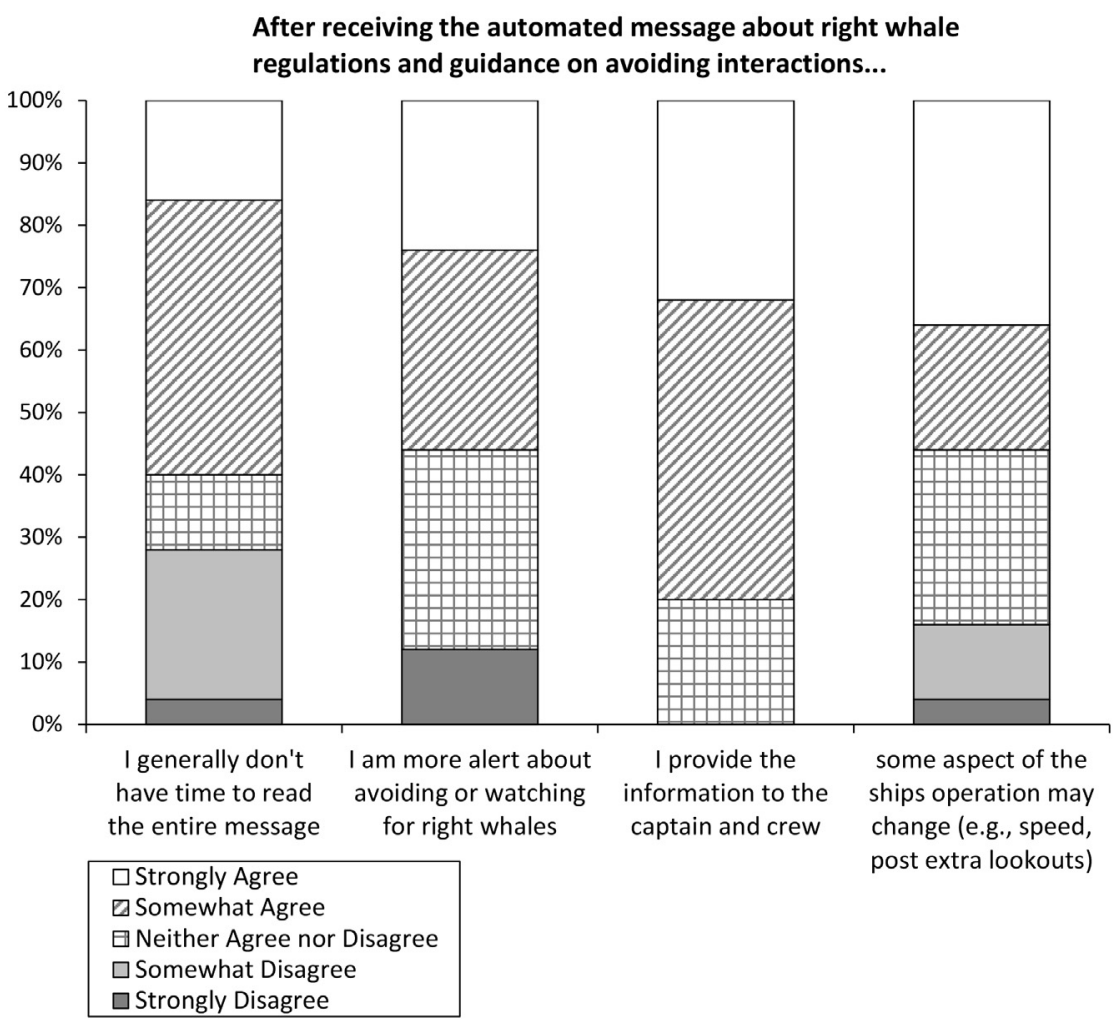

Figure 4.-Attitudes toward Mandatory Ship Reporting system automated return message containing right whale information.

ple implies that the findings are not generalizable to a larger population nor can the extent of response bias be formally identified (Pruchno et al., 2008). Previous studies comparing opportunistic samples to random samples are rare (Pruchno et al., 2008). Two studies that have compared variables of interest between these two sampling approaches suggest that sample means on variables of interest were significantly different between opportunistic and random samples (Pruchno et al., 2008; Ranmuthugala et al., 2008); thus we suggest that the results best represent only those individuals in our survey sample population.

Comments provided via the survey were varied: some indicated an awareness regarding the vulnerability of right and other whales to ship strikes, the severity of the problem, and the need to reduce this threat; others indicated that reporting, and other mea- and Silber, 2013; Laist et al., 2014; van der Hoop et al., 2014; Martin et al., 2016) - than does the MSR because the latter involves reporting only. Therefore, some mariners may have used the survey as an opportunity to express their views about the speed restrictions.

Our results are mixed on the ease of use of the MSR system by mariners. Of respondents with direct experience with the system, about $70 \%$ followed the reporting requirements and sent the report as soon as possible after entering an MSR area, and only $15 \%$ indicated the reporting requirements were difficult to follow. However, about half of respondents felt that sending the report took time away from other duties and nearly $60 \%$ said that they did not have time to read the entire return message. In addition, about $40 \%$ of all respondents felt the MSR system is an unnecessary requirement for ships.

As a conservation measure, our results suggest that the most important function of the MSR is one of education and raising awareness, as most respondents with direct experience with the program indicated that information in the return message was distributed to their crews and that crew members were generally more aware of right whales after receiving the information. Further, about half of all respondents (including those without direct MSR experience) stated the system was good for whale conservation and considered the system a good way to raise awareness about ship-whale collisions.

Being a metric difficult or impossible to reasonably quantify, mariners, of course, cannot know the overall impact of the MSR in reducing collisions with whales. However, the goal was to attempt to ascertain whether mariners disregarded the incoming message, for example, or whether their possible actions in response to some aspect of the message may have lowered the possibility of striking a whale.

Respondents were roughly equally divided in their views on whether the system was useful in avoiding 
whales. Thus, there is little doubt that the MSR has served to raise mariner awareness about the depleted status of right whales and the species' vulnerability to ship collisions because hundreds of ships have made tens of thousands of reports to (and received return messages from) the MSR in the period since its implementation (Silber et al., 2015).

Inasmuch as return messages arrive in the bridge of reporting vessels as they enter right whale habitat, this feature alone has served as a frequent reminder to those operating ships in U.S. waters about an important conservation matter - and in this regard the outgoing message has been a flexible informational tool for alerting mariners about additional large whale conservation measures as they have been developed.

More broadly, an important aspect of the MSR, a feature with international implications, is that its establishment, as one of the first formal measures to address the threat of ship-whale collisions (Johnson, 2004), helped facilitate the development of additional whale conservation measures. For example, since the implementation of the MSR, the United States and several other nations have established related IMO-adopted routing measures in their waters (Silber et al., 2012a).

In addition, outgoing MSR messages have been adapted to provide alerts about other threat-reduction measures (e.g., dynamically implemented and seasonal vessel speed restrictions) and have been used to provide written information on right whale sightings. However, in regard to information dissemination, broad-based distribution programs have also been developed by a number of entities. For example, a number of ports and government agencies now rely on a number of systems (e.g., the frequently updated USCG Broadcast Notice to Mariners) to transmit information to ships, including information about right whale sightings.

The International Whaling Commission provides brochures for mariners

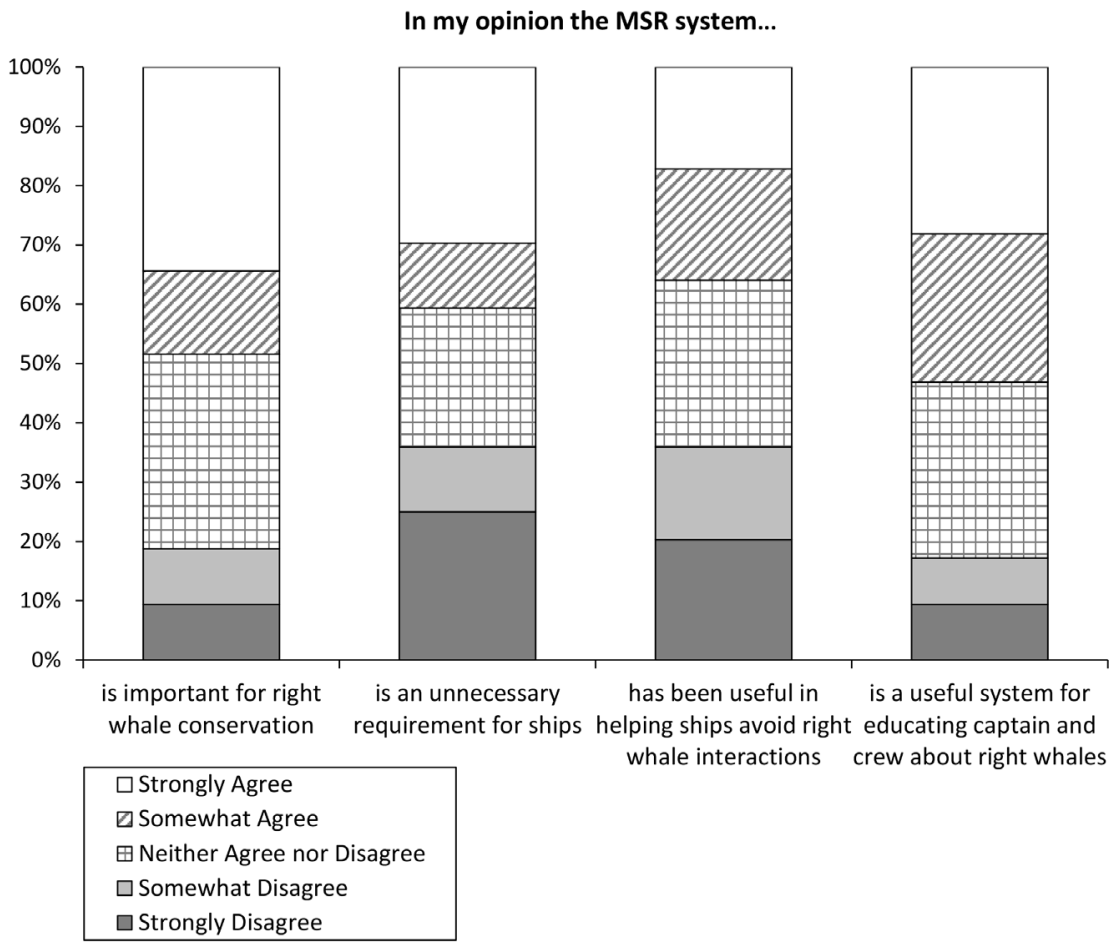

Figure 5.- General attitudes toward the Mandatory Ship Reporting system.

regarding large whale ship strikes ${ }^{6}$; numerous non-governmental organizations maintain web sites and actively distribute information on this matter; and NMFS has developed and routinely provides interactive CD's, laminated cards, and booklets ${ }^{7}$ regarding the threat of ship strikes of right whales.

Most of this material, however, is "passive" and has neither the immediacy of notifying ships directly through the MSR nor provides near real-time information about sighted whales. And, while various outlets provide near real-time whale sighting information through interagency cooperative efforts (NOAA, 2006), it is not clear if, and to what extent, mariners consult and use this information.

${ }^{6}$ Whales: collisions prevents damage to ships, and injuries to passengers, crew and whales. (https://iwc.int/index.php?cID $=3199 \& \mathrm{cType}=$ document)

${ }^{7}$ Interactive items online at www.greateratlantic. fisheries.noaa.gov/protected/shipstrike/training/ index.html.
Our results from respondents with direct experience with the MSR indicate that the system may have some utility for directly reducing the number of whale-ship collisions, as over half stated that they are more alert after receiving the incoming MSR message and about half said some aspect of the ships operation may change as a result of the message. About $35 \%$ of all respondents stated that the MSR is useful for helping ships avoid right whale interactions. Nonetheless, information on the number of known right whale deaths from ship collisions is noted below and in van der Hoop et al. (2014), and no discernable differences are apparent in fatal strike rates in the time after sighting information was routinely provided beginning in the mid-1990's via aircraft survey programs and through the MSR beginning in 1999. Therefore, the extent to which whale sighting information provided via the MSR, or any other means, plays a role in reducing the number of ship struck whales is not clear. 
One of the stated secondary purposes of the MSR was to enable the gathering of data to facilitate a better understanding of vessel operations in right whale habitat as a means to further develop conservation measures (Merrick and Cole, 2007; Silber et al., 2012a). When the MSR was established, routinely collected and archived information on vessel operations on this scale did not exist.

However, since inception of the MSR, advancing technologies are used to monitor vessel activities. In regard to monitoring U.S. port entries, systems to track vessel operations and emerging reporting requirements are far more comprehensive and precise than self-reporting under MSR protocols. Among the most important of these is the advent and use of GPSlinked VHF radio signal and satellitetransmitted Automatic Identification Systems (AIS) which are required on most ships and broadcast signals that provide detailed information on ship location, speed, and routes (Vanderlaan and Taggart, 2009; Reimer et al., 2016; Robards et al., 2016). In addition, a number of U.S. ports have Vessel Tracking Systems to aid in navigation, and some fishing vessels are required to carry Vessel Monitoring Systems.

Following the attacks of 11 September 2001, all vessels have been required to provide $96-\mathrm{h}$ notice prior to calling on a U.S. port. Some of these technologies, AIS in particular, have been used to assess changes in ship operations in response to the implementation of various whale protection measures, including routing scheme changes (Vanderlaan and Tagart, 2009; Lagueux et al., 2011), vessel speed restrictions (Lagueux et al., 2011; Wiley et al., 2011; Silber et al., 2014), and dynamically managed areas (Silber et al., 2012b). Development and use of these technologies and communication systems have rendered the MSR a less than optimal means to gather and relay information to and from ships and have therefore largely supplemented the tracking of ship operations functions of the MSR.
From 1999 (when the MSR was established) to June 2016, 11 confirmed right whale deaths resulted from collisions with ships (Laist et al., 2014; Henry $^{8}$ ), an average of 0.7 per year. This rate of known deaths attributed to ship strikes is roughly comparable to the 10 years prior to implementation of the MSR (1990-99; 0.6 per year); but the average decreased to 0.3 fatal strikes per year in the years 2007 through 2015 (Laist et al., 2014; Henry et al. ${ }^{5}$ ).

A number of factors could be involved in affecting these rates. We contend that variables such as whale distribution and shifts in distribution, particularly relative to large-scale shipping lanes, and overall shipping traffic volume, play roles in the occurrence and frequency of whale strikes. In the last decade, for example, the number of large vessel trips into U.S. east coast ports has fluctuated in response to shifting economic climates and increasing ship size and cargo capacities (the latter being a feature that reduces the number of trips overall) (DOT, 2013; MARAD, 2013; Silber et al., 2015).

In the context of these pervasive circumstances influencing the economics of transporting goods on worldwide scales, education and outreach efforts, while still important, may have little overall effect on rates of fatal ship strikes. Regardless, while the rather crude metric of annual deaths lacks sufficient resolution to fully evaluate the effects of the MSR, we note only that there were no immediate or overt changes in right whale ship strike-related death rates at the onset or in the time the MSR was in place.

Protection of living marine resources can be challenging in light of resource utilization by multiple industrial or commercial users. Conservation measures are generally established

${ }^{8}$ Henry, A. G., T. V. N. Cole, L. Hall, W. Ledwell, D. Morin, and A. Reid. 2014. Mortality determinations for baleen whale stocks along the Gulf of Mexico, United States east coast, and Atlantic Canadian provinces, 2008-12. U.S. Dep. Commer., Northeast Fish. Sci. Cent., Ref. Doc. 14-10, 17 p. (https://www.nefsc.noaa.gov/nefsc/publica tions/crd/crd1410). by incorporating the best available science and with maximum (practical) protections in mind. But such programs are not always evaluated (Clark et al., 2002; Ferraro and Pattanayak, 2006) or assessed to identify ways to optimize use of limited resources (Kapos et al., 2008) or fully utilize the provisions of available statutes.

The U.S. Government has faithfully operated the MSR for years and there is little doubt the program has conservation benefits by raising awareness of the maritime industry. Further, the MSR is one element in a suite of ship strike reduction measures that include IMO-adopted Areas To Be Avoided (Vanderlaan and Taggart, 2009), modifications of shipping routes (USCG, 2007), and voluntary and mandatory vessel speed restrictions (NOAA, 2008). However, our survey results suggest that, at least from the perspective of mariners who completed our survey, benefits of the MSR in reducing the likelihood of ships colliding with right whales are divided, but had a role in promoting education and outreach opportunities.

\section{Acknowledgments}

We are grateful for the multi-year collaboration with the USCG in designing and operating the MSR. The USCG's involvement has been invaluable. For the last several years, NOAA's Atlantic Oceanographic and Atmospheric Laboratory has managed the operation of the MSR's shipto-shore communication system. For their assistance in distributing notifications of the survey, we are grateful to Jerome Hyman of the National Geospatial Agency, Kathy Metcalf of the Chamber of Shipping of America, Bryan Wood-Thomas of the World Shipping Council, Patrick Keown and Rachel Medley of NOAA's National Ocean Service, James McLaughlin and Peter Kelliher of NOAA's Southeast Regional Office and Greater Atlantic Fisheries Regional Office, respectively, Michael Carter of the Maritime Administration, Jodie Knox of the U.S. Coast Guard, and Paula Rychtar editor of the Mariner's Weath- 
er Log. The paper was improved by review and comment by Courtney Smith and three anonymous reviewers.

\section{Literature Cited}

Asaro, M. J. 2012. Geospatial analysis of management areas implemented for protection of the North Atlantic right whale along the northern Atlantic coast of the United States. Mar. Pol. 36:915-921. (https://doi. org/10.1016/j.marpol.2012.01.004).

Bellwood, D. R., T. P. Hughes, C. Folke, and M. Nystrom. 2004. Confronting the coral reef crisis. Nature 429:827-833. (https://doi. org/10.1038/nature02691).

Bruner, A. G., R. E. Gullison, and A. Balmford. 2004. Financial costs and shortfalls of managing and expanding protected-area systems in developing countries. BioScience 54:1,119-1,126. (https://doi.org/ 10.1641/0006-3568(2004)054[1119:FCASO M]2.0.CO;2).

Clapham, P. J., S. B. Young, and R. L. Brownell, Jr. 1999. Baleen whales: conservation issues and the status of the most endangered populations. Mammal Rev. 29:35-60. (doi: https:// doi.org/ 10.1046/j.1365-2907.1999.00035.x).

Clark, J. A., J. M. Hoekstra, P. D. Boersma, and P. Kareiva. 2002. Improving U.S. Endangered Species Act recovery plans: key findings and recommendations of the SCB recovery plan project. Conserv. Biol. 16:1510-1519. (doi: https://doi.org/10.1046/j. 1523-1739.2002.01376.x).

Clinton, W. J. 1998. Statement on protecting the northern right whale. In Weekly compilation of presidential documents, p. 696. 23 April, 34(17), Wash., D.C

Conn, P. B., and G. K. Silber. 2013. Vessel speed restrictions reduce risk of collision-related mortality for North Atlantic right whales. Ecosphere 4:43. (doi: https://doi.org/10.1890/ ES13-00004.1)

DOT. 2013. Freight facts and figures. In Bur. Transp. Stat., Res. Innovative Technol. Admin., U.S. Dep. Transp. (http://www.rita.dot. gov/bts/node/493771).

Ferber, R. 1977. Research by convenience. J. Consumer Res. 4:57-58. (https://doi. org/10.1086/208679)

Ferraro, P. J., and S. K. Pattanayak. 2006. Money for nothing? A call for empirical evaluation of biodiversity conservation investments. PLoS Biol. 4(4):e105. (doi:10.1371/journal. pbio.0040105)

Halpern, B. S. 2003. The impact of marine reserves: do reserves work and does reserve size matter? Ecol. Appl. 13: S117-S137. (doi: https://doi.org/10.1890/ 1051-0761(2003)013[0117:TIOMRD]2.0. $\mathrm{CO} ; 2)$.

Hoyt, E. 2011. Marine protected areas for whales, dolphins and porpoises: a world handbook for cetacean habitat conservation and planning. Earthscan/Routledge and Taylor \& Francis, Lond., 512 p.

IUCN-WCPA. 2008. Establishing marine protected area networks - making it happen. IUCN World Commiss. Protect. Areas, NOAA and Nature Conservancy, Wash., D.C., 118 p. (https://cmsdata.iucn.org/downloads/ mpanetworksmakingithappen_en.pdf).

Johnson, L. S. 2004. Coastal state regulation of international shipping. Oceana Publ., Inc. Dobbs Ferry, N.Y., $214 \mathrm{p}$
Kapos, V., A. Balmford, R. Aveling, P. Bubb, P. Carey, A. Entwistle, J. Hopkins, T. Mulliken, R. Safford, A. Stattersfield, M. Walpole, and A. Manica. 2008. Calibrating conservation: new tools for measuring success. Conserv. Lett. 1:155-164. (doi: https://doi. org/10.1111/j.1755-263X.2008.00025.X)

Kraus, S. D., M. W. Brown, H. Caswell, C. W. Clark, M. Fujiwara, P. K. Hamilton, R. D. Kenney, A. R. Knowlton, S. Landry, C. A. Mayo, W. A. McLellan, M. J. Moore, D. P. Nowacek, D. A. Pabst, A. J. Read, and R. M. Rolland. 2005. North Atlantic right whales in crisis. Science 309:561-562. (doi: https://doi. org/10.1126/science.1111200).

Lagueux, K. M., M. A. Zani, A. R. Knowlton, and S. D. Kraus. 2011. Response by vessel operators to protection measures for right whales Eubalaena glacialis in the southeast U.S. calving ground. Endangered Species Res. 14:69-77. (doi: https://doi.org/10.3354/ esr00335)

Laist, D. W., A. R. Knowlton, and D. Pendleton. 2014. Effectiveness of mandatory vessel speed limits for protecting North Atlantic right whales. Endangered Species Res. 23:133-147. (doi: https://doi.org/10.3354/ esr00586)

Luster, J. P. 1999. The international maritime organization's new mandatory ship reporting system for the northern right whale's critical habitat: a legitimate approach to strengthening the Endangered Species Act? Naval Law Rev. 46:153-169.

MARAD. 2013. Vessel calls snapshot, 2011. U.S. Dep. Transp., Off. Pol. Plans, U.S. Marit. Admin., 10 p. (https://www.marad.dot.gov/ wp-content/uploads/pdf/Vessel_Calls_at_ US Ports Snapshot.pdf).

Martin J., Q. Sabatier, T. A. Gowan, C. Giraud, E. Guararie, C. S. Calleson, J. G. OrtegaOrtiz, C. J. Deutsch, A. Rycyk, and S. M. Koslovsky. 2016. A quantitative framework for investigating risk of deadly collisions between marine wildlife and boats. Methods Ecol. Evol. 7:42-50. (doi: https://doi. org/10.1111/2041-210X.12447).

Merrick, R. L., and T. V. N. Cole. 2007. Evaluation of northern right whale ship strike reduction measures in the Great South Channel of Massachusetts. U.S. Dep. Commer., NOAA Tech. Memo NMFS-NE-202, 12 p.

Miteva, D. A., S. K. Pattanayak, and P. J. Ferraro. 2012. Evaluation of biodiversity policy instruments: what works and what doesn't? Oxford Rev. Econ. Pol. 28:69-92. (doi: https://doi.org/10.1093/oxrep/grs009).

NOAA. 2006. Proposed rule to implement speed restrictions to reduce the threat of ship collisions with North Atlantic right whales. 71 Fed. Regist. 36299 (26 June 2006), p. 36,299-36,313. (avail. online at https://federalregister.gov/a/06-5669).

2008. Final rule to implement speed restrictions to reduce the threat of ship collisions with North Atlantic right whales. 73 Fed. Regist. 60173 (10 Oct. 2009), p. 60,173-60,191. (avail. online at https://federalregister.gov/d/E8-24177).

2015. Proposed expansion, regulatory revision and new management plan for the Hawaiian Islands Humpback Whale National Marine Sanctuary. 80 Fed. Regist. 16223 (19 June 2015), p. 16,223-16,247 (avail. online at https://federalregister. gov/d/2015-06441).
Pruchno, R., J. Brill, Y. Shands, J. R. Gordon, M. Genderson, M. Rose, and F. Cartwright. 2008. Convenience samples and caregivin research: how generalizable are the findings? Gerontologist 48(6):820-827.

Ranmuthugala, G., M. Karr, M. Mira, G. Alperstein, J. Causer, and M. Jones. 2008. Opportunistic sampling from early childhood centres: a substitute for random sampling to determine lead and iron status in preschool children? Aust. N.Z. J. Public Health 22(4):512-514.

Reimer, J., C. Gravel, M. W. Brown, and C. T. Taggart. 2016. Mitigating vessel strikes: the problem of the peripatetic whales and the peripatetic fleet. Mar. Pol. 68:91-99. (https://doi.org/10.1016/j.marpol.2016.02 0170308-597X)

Rodrigue, J. P., C. Comtois, and G. Slack. 2017. The geography of transport systems. Routledge, N.Y., 440 p. (https://people.hofstra. edu/geotrans/index.html)

Robards, M. D., G. K. Silber, J. D. Adams, J. Arroyo, D. Lorenzini, K. Schwehr, and J. Amos. 2016. Conservation science and policy implications of the marine vessel Automatic Identification System (AIS)-a review. Bull. Mar Sci. 92:75-103. (doi: https://doi.org/10.5343/ bms.2015.1034)

Selig, E. R., and J. F. Bruno. 2010. A global analysis of the effectiveness of marine protected areas in preventing coral loss. PLoS One 5(2):e9278. (https://doi.org/10.1371/ournal.pone.0009278).

Silber, G. K., and S. Bettridge. 2012. An assessment of the final rule to implement vessel speed restrictions to reduce the threat of vessel collisions with North Atlantic right whales. U.S. Dep. Commer., NOAA Tech. Memo. NMFS-OPR-48, $114 \mathrm{p}$.

A. S. M. Vanderlaan, A. Tejedor Arceredillo, L. Johnson, C. T. Taggart, M W. Brown, S. Bettridge, and R. Sagarminaga. 2012a. The role of the International Maritime Organization in reducing vessel threat to whales: Process, options, action and effectiveness. Mar. Pol. 36(6):1,2211,233. (doi: https://doi.org/10.1016/j.marpol. 2012.03.008)

D. Adams, and S Bettridge. 2012b. Vessel operator response to a voluntary measure for reducing collisions with whales. Endangered Spec. Res. 17:245-254. (doi: https://doi.org/10.3354/esr00434).

C. J. Fonnesbeck

2014. Compliance with vessel speed restrictions to protect North Atlantic right whales PeerJ 2:e399. (doi: https://doi.org/10.7717/ peerj.399).

M. J. Asaro, T. Cole, K. S. Moore, L. I. Ward, and B. J. Zoodsma. 2015. The right whale Mandatory Ship Reporting system: a retrospective. PeerJ 3:e866. (doi: https://doi.org/10.7717/ peerj.866)

USCG. 2001. Mandatory Ship Reporting systems. Final Rule. 66 Fed. Regist. 58066 (20 Nov. 2001), p. 58,066-58,070. (avail. online at https://federalregister.gov/d/01-28964).

2007. Port access route study of potential vessel routing measures to reduce vessel strikes of North Atlantic right whales. 72 Fed. Regist. 64968 (19 Nov. 2007), p 64,968-64,970. (avail. online at https://federalregister.gov/d/E7-22557) 
van der Hoop, J. M., A. S. M. Vanderlaan, T. V. N. Cole, A. G. Henry, L. Hall, B. MaseGuthrie, T. Wimmer, and M. J. Moore. 2014. Vessel strikes to large whales before and after the 2008 Ship Strike Rule. Conserv. Lett. 8:24-32. (doi: https://doi.org/10.1111/ conl.12105).

Vanderlaan, A. S. M., and C. T. Taggart. 2009. Efficacy of a voluntary area to be avoid- ed to reduce risk of lethal vessel strikes to endangered whales. Conserv. Biol. 23:1,467-1,474.(doi:https://doi.org/10.1111/j.15231739.2009.01329.x).

Ward-Geiger, L. I., G. K. Silber, R. D. Baumstark, and T. L. Pulfer. 2005. Characterization of ship traffic in right whale critical habitat. Coast. Manage. 33:263-278. (doi: https://doi. org/10.1080/08920750590951965).
Wiley, D. N., M. Thompson, R. M. Pace III, and J. Levenson. 2011. Modeling speed restrictions to mitigate lethal collisions between ships and whales in the Stellwagen Bank National Marine Sanctuary, USA. Biol. Conserv. 144:2,377-2,381. (doi: https://doi. org/10.1016/j.biocon.2011.05.007). 
Appendix 1.-Mandatory Ship Reporting systems survey instrument.

\section{Right Whale Mandatory Ship Reporting System: What do you think?}

The National Marine Fisheries Service, the federal agency responsible for the

stewardship of living marine resources and their habitats, is sponsoring a survey to

obtain mariner's feedback on the North Atlantic right whale Mandatory Ship

Reporting (MSR) system. (To find out more about the MSR system go here)

This survey is only about the reporting system. It is not about the ship speed restrictions or any other right whale conservation program.

This is a voluntary survey. Your feedback will be used to evaluate and improve the MSR system. All survey responses are anonymous and confidential.

OMB Control No. 0648-xxxx. Expiration Date: $x x / x x / x x x x$. Public reporting burden for this information collection is estimated to average 10 minutes per response. Send comments regarding this burden estimate or other suggestions for reducing this burden to Kristy Wallmo, 301-427-8190 or Kristy.Wallmo@noaa.gov.

Responses are kept confidential as required by section $402(b)$ of the Magnuson-Stevens Act and NOAA Administrative Order 216-100, Confidentiality of Fisheries Statistics, and will not be released for public use except in aggregate statistical form without identification as to its source. Notwithstanding any other provisions of the law, no person is required to respond to, nor shall any person be subjected to a penalty for failure to comply with, a collection of information subject to the requirements of the Paperwork Reduction Act, unless that collection of information displays a currently valid OMB Control Number.

1. Are you aware of the North Atlantic right whale MSR (MSR) system?

$\square$ Yes

$\square \quad$ No. If 'No' survey will skip to Q7.

2. During the year, about how many times do you enter one of the MSR areas?

$\square \quad$ I enter one of the MSR areas on a regular basis

If box above is checked, survey will prompt: Approximately times per year

$\square$ I have entered at least one of the MSR areas but not on a regular basis. Approximately times.

$\square \quad$ I have not entered either of the MSR areas. If checked, survey will skip to Q6c.

3. Which MSR area do you enter most frequently?
$\square$ North MSR area
$\square$ South MSR area

$\square$ About the same amount for both areas

4. When you enter a MSR area, how often do you send a report as part of the MSR system?
$\square$ Always
$\square$ Most of the time
$\square$ Some of the time
$\square$ Rarely
$\square$ Never 
5. After sending in a report to the MSR system, have you received a message about right whale regulations and guidance on how to avoid interactions with right whales?
$\square$ Yes
$\square$ No

6. Please check the box that best represents your level of agreement with each statement.

\begin{tabular}{|c|c|c|c|c|c|}
\hline & $\begin{array}{l}\text { Strongly } \\
\text { Agree }\end{array}$ & $\begin{array}{l}\text { Somewhat } \\
\text { Agree }\end{array}$ & $\begin{array}{l}\text { Neither } \\
\text { Agree nor } \\
\text { Disagree }\end{array}$ & $\begin{array}{l}\text { Somewhat } \\
\text { Disagree }\end{array}$ & $\begin{array}{l}\text { Strongly } \\
\text { Disagree }\end{array}$ \\
\hline \multicolumn{6}{|l|}{ 6a. After entering one of the MSR areas... } \\
\hline $\begin{array}{l}\text {.... it is relatively easy to send in the } \\
\text { required report }\end{array}$ & $\square$ & $\square$ & $\square$ & $\square$ & $\square$ \\
\hline $\begin{array}{l}\text {...I generally follow the report format } \\
\text { exactly as specified in the instructions }\end{array}$ & $\square$ & $\square$ & $\square$ & $\square$ & $\square$ \\
\hline .... send in the report as soon as possible & $\square$ & $\square$ & $\square$ & $\square$ & $\square$ \\
\hline $\begin{array}{l}\text {...sending in the required report takes } \\
\text { time away from other duties I have on } \\
\text { the ship }\end{array}$ & $\square$ & $\square$ & $\square$ & $\square$ & $\square$ \\
\hline \multicolumn{6}{|c|}{$\begin{array}{l}\text { 6b. After receiving the automated message about right whale regulations and guidance on avoiding } \\
\text { interactions with right whales... }\end{array}$} \\
\hline $\begin{array}{l}\text {...I generally don't have time to read the } \\
\text { entire message }\end{array}$ & $\square$ & $\square$ & $\square$ & $\square$ & $\square$ \\
\hline $\begin{array}{l}\text {...I am more alert about avoiding or } \\
\text { watching for right whales }\end{array}$ & $\square$ & $\square$ & $\square$ & $\square$ & $\square$ \\
\hline $\begin{array}{l}\text {...I provide the information to the captain } \\
\text { and crew }\end{array}$ & $\square$ & $\square$ & $\square$ & $\square$ & $\square$ \\
\hline $\begin{array}{l}\text {...some aspect of the ship's operation } \\
\text { may change (e.g. speed, post extra } \\
\text { lookouts) to avoid an interaction as a } \\
\text { result of having received the message }\end{array}$ & $\square$ & $\square$ & $\square$ & $\square$ & $\square$ \\
\hline \multicolumn{6}{|l|}{ 6c. In my opinion the MSR system... } \\
\hline $\begin{array}{l}\ldots \text { is important for right whale } \\
\text { conservation }\end{array}$ & $\square$ & $\square$ & $\square$ & $\square$ & $\square$ \\
\hline $\begin{array}{l}\text {...is an unnecessary requirement for } \\
\text { ships }\end{array}$ & $\square$ & $\square$ & $\square$ & $\square$ & $\square$ \\
\hline $\begin{array}{l}\text {...has been useful in helping ships avoid } \\
\text { right whale interactions }\end{array}$ & $\square$ & $\square$ & 口 & $\square$ & $\square$ \\
\hline $\begin{array}{l}\text {...is a useful system for educating } \\
\text { captains and crew about right whales }\end{array}$ & $\square$ & $\square$ & $\square$ & $\square$ & $\square$ \\
\hline
\end{tabular}


7. How many years have you worked in the maritime industry?

(a) How many years as a crew member?

(b) How many years as a captain?

8. What type of ship do you work on?

Thank you very much for your participation in this survey. Your feedback will help NOAA Fisheries improve the North Atlantic Right Whale MSR system. Please add any additional comments you have concerning the MSR system in this box.

Type comments here 
Appendix 2.-Communications channels used to notify users of an online survey of Mandatory Ship Reporting systems.

\section{Federal Agencies}

NOAA's Ocean Service. Regional Navigation Managers work directly with pilots, mariners, port authorities, and recreational boaters to help identify and address marine transportation system navigational safety issues. Based on our request, U.S. east coast navigation managers used their regular public and industry meetings, port facility functions, and other conduits to notify mariners about the survey.

National Geospatial Agency (NGA). The NGA's Notice To Mariners (msi. nga.mil/NGAPortal/MSI.portal? $\mathrm{nfpb}=$ true\&_st $=$ \&_pageLabel $=\mathrm{msi}$ portal_page_61, ) is the principal publication for ships engaged in international voyages. Designed to ensure the safety of life at sea, this publication provides marine safety information and corrections to navigational aids for all U.S. Government navigation charts and publications derived from a variety of sources, both foreign and domestic. A special notice about the survey was posted in the NGA's Hydrogram and Marine Information sections of the weekly notice on 10 June 2015 (msi.nga.mil/MSISiteContent/StaticFiles/NAV_PUBS/ UNTM/201525/Marine_Info.pdf) and again on 3 September 2015.

Maritime Administration (MARAD). The Department of Transportation's MARAD is charged with ensuring that the nation maintains adequate shipbuilding and repair services, efficient ports, and reserve shipping capacity for use in time of national emergency (www.marad.dot.gov/). It promotes maintenance of a well-balanced U.S. merchant fleet for transport of waterborne commerce, and it is capable of service as a naval and military auxiliary in time of war. MARAD promoted the MSR survey with an announcement via its distributions list, contain- ing perhaps several thousand active mariners. Announcement by email distribution sent on 27 July 2015.

NOAA, NMFS, Northeast Regional Office. Participating members of maritime contact distribution lists were encouraged via email to take the survey by shipping industry liaisons from both NOAA's NMFS Southeast and Northeast Regional Offices on 7 July 2015. The survey was also discussed by liaisons at numerous industry meetings.

U.S. Coast Guard (USCG). The USCG's outreach program posted a blog about the survey on 6 November 2015. On average, the blog receives approximately 40,000 unique (each coming from a different IP address) views per month.

\section{Industry Associations}

World Shipping Council (WSC). With 26 companies, which utilize hundreds of ships and employ hundreds of vessel operators, the WSC represents over $90 \%$ of global liner vessel capacity and transport cabilities. At our request, the WSC sent notifications to all of its member companies on two occasions (28 July and 30 August 2015).

Chamber of Shipping of America (CSA). The CSA represents 35 U.S.based companies that own, operate, or have commercial interest in oceangoing tankers, containers, and dry bulk vessels engaged in domestic and international trades. These entities employ hundreds of vessel operators. The CSA sent notifications about the survey to each of its member companies on two occasions (15 July and 8 August 2015). The CSA also asked a number of other industry associations to notify their members; these included InterTanko, American Waterways Operators (AWO), Cruise Lines International Association (CLIA), International Chamber of Shipping (ICS), and Baltic and International Maritime Council (BIMCO).

Just for information: InterTanko has 204 members and 236 companies whose combined fleet comprises some 3,077 tankers; AWO is the national trade association for the U.S. tugboat, towboat, and barge industry; CLIA is the world's largest cruise industry trade association; ICS membership represents national shipowners' associations in Asia, Europe, and the Americas whose member shipping companies operate over $80 \%$ of the world's merchant tonnage; BIMCO is the largest of the international shipping associations representing shipowners and its membership controls around 65 percent of the world's tonnage.

Passenger Vessel Association. The PVA represents companies who are owners, operators, and leasers of shipboard operations of passenger vessels on the waterways of the United States and Canada including car and passenger ferries, tour and excursion vessels, charter boats, eco-tour boats, and day sailing vessels. These vessels move over 200 million passengers each year. The PVA sent notification of the MSR survey to all its members on 5 August 2015.

\section{Maritime Periodicals}

Mariner's Weather Log. A publication of the National Weather Service (NWS), this journal (http://www.vos. noaa.gov/mwl.shtml) allows the NWS to maintain contact and communicate with over 10,000 shipboard observers worldwide. It is used to distribute meteorological information, worldwide environmental impact concerns, climatology studies, and the like to the maritime community. A special announcement (including a small story and photograph) appeared in the $\mathrm{Au}-$ gust 2015 (Vol. 59, No. 2) issue (www. vos.noaa.gov/MWL/201508/msrsurvey.shtml) 